\title{
Community Expectancy in Urban Farming Participation
}

\section{Noriah Othman, Rabiatul Adawiyah Latip, Mohd Hisham Ariffin, Noralizawati Mohamed}

Faculty of Architecture, Planning and Surveying, Universiti Teknologi MARA, 40450 Shah Alam, Malaysia

noriaho@yahoo.com

\begin{abstract}
Urban farming is seen as a sustainable practice with the social, economic and urban environment benefits. Despite the efforts by the government, there is lack of public participation in urban farming activities and challenges in sustaining urban farming participants' interest. The study is aimed at measuring urban farming participation motivations using the Expectancy Theory of Motivation which is made up of three aspects; namely expectancy, instrumentality and valence. This paper describes the findings regarding the expectancy aspect of motivation (measured by using Expectancy theory) in urban farming activity in Malaysia.
\end{abstract}

Keywords: Expectancy, Urban farming, Motivational factor, Sustainable practice

eISSN 2398-4279 @ 2018. The Authors. Published for AMER ABRA cE-Bs by e-International Publishing House, Ltd., UK. This is an open access article under the CC BY-NC-ND license (http://creativecommons.org/licenses/by$n c-n d / 4.0 /$ ). Peer-review under responsibility of AMER (Association of Malaysian Environment-Behaviour Researchers), ABRA (Association of Behavioural Researchers on Asians) and CE-Bs (Centre for EnvironmentBehaviour Studies), Faculty of Architecture, Planning \& Surveying, Universiti Teknologi MARA, Malaysia.

DOI: https://doi.org/10.21834/ajqol.v3i13.157 


\subsection{Introduction}

Urban farming is widely defined as "an industry located within (intra-urban) or on the fringe (peri-urban) of a town, a city or a metropolis, which grows or raises, processes and distributes a diversity of food and non-food products, (re-)using mostly human and material resources, products and services found in and around that urban area, and in turn supplying human and material resources, products and services mainly to that urban area (Mougeot, 2000). Ackerman (2012) defined urban farming as the yielding of foods within cities. According to Recknagelet et al. (2016), urban farming is the producing of agricultural plants, poultry, or livestock on public or private property within city limits. In this research, urban farming is not seen as an industry but as cultivation practices that occur in urban areas. In the Malaysian context, urban farming is defined as the practice of planting, processing and distribution of agricultural products in the city and surrounding areas, whether using natural resources and recycled waste in the production of crops and livestock diversity, and for recreation and relaxing (DOA, 2016). Farming in Malaysia is traditionally understood as the planting of vegetable and fruit crops practiced by smallholders in rural areas. But urban farming is currently seen as having important roles of curbing the impact of rising food prices, reducing urban poverty and food insecurity, supplementing people's income and easing the financial burdens of urban dwellers (Nasrudin et al., 2010). Thus, there are many varying definitions of urban farming due to differences in types of land, areas of practices, types of products and the perceptions of definers themselves. In this research, urban farming is viewed as nonindustrial cultivation practices that occur in urban areas.

There is the challenge of declining food production due in part to global warming, floods, droughts, increase in temperatures, challenges in rainfall patterns and rising sea levels. Malaysia is one of the many countries with annual decreases in food self-sufficiency (Ariffin, Abas \& Baluch, 2015). According to Omar (2016), two-thirds of Malaysians are living in cities. The rise of the urban population is due to the increasing rate of urban migration and transformation of rural settlements into the urban settlements. This has led to the issues of urban poverty, loss of community belonging, and social isolation. These issues affect the quality of urban living. According to Dahlan et al. (2016) the pleasant physical environment facilitates close relationship building and increases opportunities to socialize and engage in activities. The promotion of relationships within neighbourhood communities can contribute to positive psychological aspects of safety (Naghibi et al., 2015). Additionally, Mat and Abdul Majid (2015) stated the importance of urban farming as an alternative way of fulfilling the need for food and for eradicating urban poverty. Urban farming has been championed in recent years as a solution to a host of issues, from food insecurity in urban communities to employment and environmental sustainability.

Thus, the Malaysian government promotes community activities through urban farming. Urban farming can give urban dwellers supplementary incomes through the surplus agricultural output and for creating a safe and peaceful urban environment through environmental design principles, security and community development. In addition, physical activities of urban farming help to upgrade the productivity of urban dwellers through gains in their physical and mental health (Musthafa et al., 2015). It can also foster awareness, interest and participation in agriculture; resulting in increased prosperity and happiness in the 
urban environment. These benefits justify the need to increase and sustain urban farming participation.

\subsection{Literature Review}

\subsection{Urban Farming Movement}

Farming has long contributed to the Malaysian economy in the post-independence era and indirectly plays a key role as food supplier and employment for rural people (Abu Dardak, 2015). Malaysian urban farming is relatively recent and less well known. The development of urban farming has two concurrent paths, one led by the NGOs (non-governmental organizations) and the other by the private sector (Boon Sung, 2013).

Urban farming in Malaysia is carried out under Program Bumi Hijau and Pembangunan Keluarga Tani. These programs are extensions of the Rancangan Buku Hijau plan initiated by the then prime minister of Malaysia, Tun Abdul Razak Hussein in 1974. Rancangan Buku Hijau helped to mitigate the economic crisis and food security problems, and was effective in reducing the rate of inflation by raising household's income through involvement in agriculture. However, in the early 1980's, agriculture was neglected despite its success in tackling inflation due to falling rubber prices, a new economic crisis and increasing emphasis on industrialization in urban areas. On $3^{\text {rd }}$ March 2006, the prime minister of Malaysia, Tun Abdullah Ahmad Badawi, introduced the Kempen Bumi Hijau campaign. The campaign led to Program Bumi Hijau and Pembangunan Keluarga Tani programmes being launched, thus encouraging the urban dwellers to participate in farming and rearing chickens and fish, or both for their own use. The main goal of this program is mitigating the food security problems by involving the country's population in tillage and rearing to produce their own food.

Table 1: Number of Locations of Urban Farming in Malaysia (Until July 2016)

\begin{tabular}{lcccc}
\hline Category & 2014 & 2015 & 2016 & Total \\
\hline Residential (Individual) & 63 & 333 & 200 & 596 \\
Residential (Community) & 87 & 118 & 84 & 289 \\
Schools & 75 & 287 & 145 & 507 \\
Institutions/Public/Private & 55 & 185 & 106 & 346 \\
Total & $\mathbf{2 8 0}$ & $\mathbf{9 2 3}$ & $\mathbf{5 3 5}$ & $\mathbf{1 7 3 8}$ \\
\hline
\end{tabular}

Source: Department of Agriculture Malaysia (2016)

From the year 2014 to the year 2016, support from government and related agencies helped make urban farming in Malaysia increase rapidly among urban communities, especially in the low-cost residential areas. The cultivation areas are the compounds of house, institutions and offices, government reserve land and suitable wasteland. The respective State Departments of Agriculture (DOA) determined the areas of activity, type of category and suitable crops to plant. These urban farming programs led to annual increases in the numbers of urban farmers; thus progressing towards achieving the aim to encourage urban dwellers to grow and produce their own food. Urban farming is also a constituent program in Local Agenda 21 (LA21) Malaysia. LA21 was established to promote sustainable development at the local level by creating and strengthening cooperation between local 
authorities, local communities and the private sector. To support this agenda, local authorities in Malaysia planned various strategies and initiatives at neighbourhood community. In 2014, there were 280 urban farming locations registered with Department of Agriculture Malaysia. In early 2016, urban farming in Malaysia was found at 535 locations throughout Malaysia. Table 1 refers to the number of locations of urban farming in Malaysia from 2014 until July 2016.

\subsection{Expectancy Theory of Motivation}

Expectancy theory of motivation by Vroom (1964) has three key elements: expectancy, instrumentality, and valence (Figure 1). The theory explains motivation on the basis to which an effort is perceived to lead to performance, performance leads to rewards, and the rewards offered are desirable (Purvis et al., 2015). As shown in Figure 1, a person is motivated because he or she (a) strongly believes that suitable effort will lead to the required performance (high expectancy), (b) strongly believes that performance will result in obtaining an outcome (high instrumentality), and (c) highly desires the outcome (high valence). The theory is useful to organizations' management for motivating employees (de Simone, 2015). Motivation is defined as psychological forces that determine the direction of a person's behavior in an organization, a person's level of effort and a person's level of persistence (George and Jones, 2012). There are intrinsic motivations and extrinsic motivations that lie on the same motivation continuum. An intrinsically motivated person is moved to act for the inherent satisfactions while an externally motivated person is driven to act due to external influences, pressures, or rewards. In humans, intrinsic motivation is a pervasive and important form of motivation. It is not the only form of motivation, or even of volitional activity. There is also extrinsic motivations that are instrumental. The extrinsically motivated person acts either because it either entails personal endorsement and a feeling of choice, or because it merely involves compliance with an external control (Ryan and Deci, 2000).

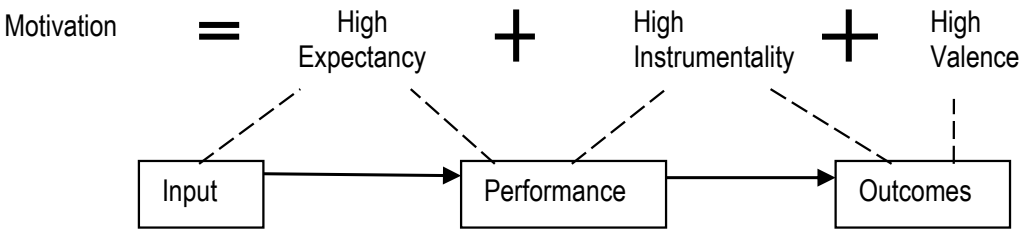

Figure 1: The Expectancy Theory (adapted from George and Jones, 2012)

\subsection{Methodology}

In selecting the study areas, preliminary work was done through face to face interviews and telephone conversations with representatives from Department of Agriculture Malaysia (DOA) at Klang Valley, Malaysia. From the information obtained in the preliminary work, community gardens which were active urban farming activity areas were selected. Other selection criteria of the community gardens were the duration of involvement, community 
engagement, stakeholder initiatives and the outreach the community gains through their participation. The duration of involvement in urban farming activities was a criteria because duration of participation affects the knowledge, motivation, rewards and experiences of the practitioners. Strong community engagement of urban farming was a criteria because it is a factor for sustaining urban farming participation in any community. The outreach of the community is indicated by the community gardens participants' experience, engagement and expertise on the urban farming activities. Such information were publicised due to the outreach through newspapers, magazines, television programs and online sources. Data was collected through a quantitative questionnaire survey that inquired about the respondent profile, current practices of urban farming, motivating factors, and challenges in participating in urban farming. The subjects were urban dwellers who participated in the community garden in their respective neighbourhood area. The respondents are 243 practitioners of urban farming at the selected community gardens. Descriptive statistics were used to analyse the data collected from the questionnaire survey. Only the findings regarding the respondent's expectancy aspect of motivation are reported in this paper.

\subsection{Results and Discussion}

Table 2: Socio-demographic Characteristics of Participants

\begin{tabular}{clcc}
\hline \multirow{3}{*}{ Gender } & Items & Frequency & Percentage $(\%)$ \\
\hline \multirow{5}{*}{ Age } & Male & 100 & 41.2 \\
& Female & 143 & 58.8 \\
& Total & 243 & 100 \\
& $<20$ & & \\
& $21-30$ & 3 & 1.2 \\
& $31-40$ & 4 & 1.6 \\
& $41-50$ & 82 & 33.7 \\
& $51-60$ & 63 & 25.9 \\
& $>60$ & 55 & 22.6 \\
& Total & 36 & 14.8 \\
& Single & 243 & 100 \\
& Married & 6 & 2.5 \\
& Widow & 225 & 92.6 \\
& Total & 12 & 4.9 \\
& Malay & 243 & 100 \\
& Chinese & 165 & 67.9 \\
& Indian & 68 & 28.0 \\
& Total & 10 & 4.1 \\
& $<$ Status & 243 & 100 \\
& RM2000 & 41 & 16.9 \\
& RM2001-RM4000 & 130 & 53.5 \\
& RM4001-RM6000 & 52 & 21.4 \\
& RM6001-RM8000 & 16 & 6.6 \\
& $>$ RM8000 & 4 & 1.6 \\
& Total & 243 & 100 \\
\hline \multirow{6}{*}{ Household Income } & &
\end{tabular}

The respondent demography is shown in Table 2. There was 100 males (41.2\%) and 143 
females (58.8\%). Respondents aged between 31 to 40 years old constitute the largest percentage (33.7\%) and those aged from 41 to 50 years old constitute the second high percentage of $25.9 \%$. These two statistics showed that respondents were in the productive workforce category of the population. Respondents aged over 60 years old constitutes $14.8 \%$. Thus, it is fair to say that this respondent group is retirees. The least number of respondents were aged below 20 years old. This implied the relative lack of interest among the young in urban farming. Respondents in the lower income group with monthly household income below RM4000.00 per month constitute $53.5 \%$ of the respondents. Those with household income over RM8,000.00 a month are from the high-income group and constitutes $1.6 \%$ of respondents.

Table 3 shows the time period of the respondents' engagement in urban farming. It shows that the majority of respondents (168 out of 243) practices urban farming for long as 2 to 4 years. The statistic reflects the success of the promotion of the Malaysian urban farming program in Malaysia which was introduced in the year 2013. Practitioners in the 2 to 4 years experience category highly practiced urban farming (1 to 3 days per week). This time amount spent implies the existence of time constraints among these practitioners due to work and family obligations. A high number of pensioner practitioners spent 6 to 7 days per week at the community garden. They said that they expected that gardening could fill their time and enhanced their social bonding with other community members in their neighbourhood. These findings in line with Engelbrech (2011) where the time period of engagement (experience) is a critical factor in influencing people's motivation in any activity.

Table 3: Time Period of Engagement in Urban Farming

\begin{tabular}{ccccc}
\hline Time Period & \multicolumn{2}{c}{ Time Spending in Community } & Garden (Weekly) & \multirow{2}{*}{ Total } \\
\cline { 2 - 4 } Engagement (Year) & $\mathbf{1 - 3}$ days & $\mathbf{4 - 5}$ days & $\mathbf{6 - 7}$ days & \\
\hline$<1$ year & 54 & 16 & 1 & 71 \\
2-4 years & 98 & 59 & 11 & 168 \\
5-7 years & 0 & 4 & 0 & 4 \\
Total & 152 & 79 & 12 & $\mathbf{2 4 3}$ \\
\hline
\end{tabular}

Table 4 shows the practitioners' expectations towards urban farming activity in aspects of social, physical and mental health, economy and environment. It is found that respondents expected that their involvement in urban farming to give physical and mental health benefits. The scores are in the upper range thus denoting high expectancy. This finding supports Davies et al. (2014) who found that growing food and gardening activity is good for health and wellbeing. Bellows et al. (2005) stated that gardening promotes plant-human relationships to induce relaxation and to reduce stress, fear and stabilize blood pressure. The social aspect is ranked second highest in the mean scores. It indicated that the respondents expected that if they participate in the urban farming activity, they can enhance social bonding in a community, build a social network and develop relationships with new farmers. However, the economic expectancy aspect has the lowest scores. This finding contradicted Abd.Rahman et al. (2013) who stated that growing own food would save substantial household expenditure because urban dwellers with low household income spent $40-60 \%$ of family income for food yearly. Lastly, the respondents expected their participation in urban 
farming to give environmental benefits in term of beautification, the aesthetic value of neighbourhood and reduced pollution.

The results also show Malaysian urban farmers expect their urban farming participation to give physical and mental health, and social interaction benefits. This finding is congruent with previous researchers that found growing food and gardening activity are good for health, promotes plant-human relationships to induce relaxation and reduction of stress, fear and anger and blood pressure (Davies et al., 2014; Bellows et al., 2005). In our study, the expectation of urban farming for economical benefits had the lowest scores despite the majority of the respondents coming from the low-income group and a significant number of pensioner respondents. This may be due to the relatively short period since 2014 that transpired from the start of the local authorities' promotion of urban farming among their constituent residents. This implies that the respondents were not convinced of the economic benefits as they have yet to see strong evidence of economic benefits of urban farming by other people.

Table 4: Expected Benefits of Urban Farming

\begin{tabular}{|c|c|c|}
\hline Category & Items & Mean \\
\hline \multirow{3}{*}{ Social } & $\begin{array}{l}\text { If I participate in the urban farming activity, I believe I can enhance social } \\
\text { bonding in a community. }\end{array}$ & 4.12 \\
\hline & $\begin{array}{l}\text { If I participate in the urban farming activity, I believe I can build my social } \\
\text { network. }\end{array}$ & 4.11 \\
\hline & $\begin{array}{l}\text { If I participate in the urban farming activity, I believe I can develop my } \\
\text { relationship with new farmers. }\end{array}$ & 4.10 \\
\hline \multirow{3}{*}{$\begin{array}{l}\text { Physical and } \\
\text { Mental Health }\end{array}$} & If I doing the farming activity, I believe I can improve my nutrition level. & 4.18 \\
\hline & If I doing the farming activity, I believe I can release my tense. & 4.17 \\
\hline & $\begin{array}{l}\text { If I doing the farming activity, I believe I can improve my mental and health } \\
\text { wellbeing. }\end{array}$ & 4.16 \\
\hline \multirow{3}{*}{ Economy } & If I doing the farming activity, I believe I can produce foods from my crops. & 3.92 \\
\hline & If I doing the farming activity, I believe I can generate my side income. & 3.74 \\
\hline & $\begin{array}{l}\text { If I doing the farming activity, I believe I can supply my food and subsistence of } \\
\text { family. }\end{array}$ & 3.74 \\
\hline \multirow{3}{*}{ Environment } & $\begin{array}{l}\text { If I participate in the urban farming activity, I believe it can beautify my } \\
\text { neighbourhood area. }\end{array}$ & 4.07 \\
\hline & $\begin{array}{l}\text { If I participate in the urban farming activity, I believe it can reduce pollution for } \\
\text { a sustainable environment. }\end{array}$ & 4.06 \\
\hline & $\begin{array}{l}\text { If I participate in the urban farming activity, I believe it can enhance the image } \\
\text { and aesthetic value of neighbourhood. }\end{array}$ & 4.03 \\
\hline
\end{tabular}

Notes: 1-Strongly Disagree, 2-Disagree, 3-Moderate, 4-Very Agree, 5-Strongly Agree

The respondents expect that their urban farming activities would give them social, health, environmental and economic benefits. Hence, part of the measures to increase urban farming participation is firstly, the relevant local authorities publicise evidence of the benefits of urban farming to the non-participants. Secondly, the local authorities should provide strong evidence of the economic benefits arising from urban farming to also sustain the existing 
participation rates.

A limitation of the reported finding here is the expectancy does not entirely equate to motivation from the perspective of the Expectancy Theory. High levels of valence and instrumentality are also needed to indicate high motivation. Furthermore, motivation is made up of intrinsic and extrinsic motivations. The items reported are only related to extrinsic motivations.

\subsection{Conclusion}

The research findings indicated the urban farmers in the study participated in urban farming because they expected resulting social, health, environmental and economic benefits. Thus, local authorities may be able to contribute to increasing urban farming participation by several initiatives including an effort to publicise the benefits of urban farming to both participants and non-participants.

\section{Acknowledgement}

The authors wish to thank Faculty of Architecture, Planning and Surveying, UniversitiTeknologi MARA (UiTM) and Research Management Institute (RMI), UiTM for permission to conduct the research. Financial assistance for this research is funded by Minister of Higher Education (MOHE) under Fundamental Research Grant Scheme (FRGS): FRGS/1/2015/SS07/UITM/02/1.

\section{References}

Abd Rahman, N., Idris, K., Tajuddin, Z., \& Abdullah, F. (2013).TransformasiPertanian Bandar. Serdang, Malaysia: PusatTransformasiKomunitiUniversiti (UCTC UPM).

Abu Dardak, R. (2015). Transformation of Agricultural Sector in Malaysia through Agricultural Policy. Kuala Lumpur: Malaysian Agricultural Research and Development Institute (MARDI).

Ackerman, K. (2012). The Potential for Urban Agriculture in New York City: Growing Capacity, Food Security \& Green Infrastructure. Urban Design Lab, Earth Institute Columbia University.

Agustina, I., \&Beilin, R. (2012). Community Gardens: Space for Interactions and Adaptations. Procedia - Social and Behavioral Sciences, 36, 439-448.

Ariffin, A. S., Abas, Z., \& Baluch, N. (2015). Issues and Challenges of Integrated Agro-Food Supply Chain: An Overview of Malaysian Food Security. Australian Journal of Basic and Applied Sciences, 9(13), 171-174.

Bellows, A. C., Brown, K., \&Smit, J. (2005).Health Benefits of Urban Agriculture. Community Food Security Coalition (CFSC), North American Initiative on Urban Agriculture Committee.

Berhanu, M. A., \& Akola, J. (2016).Environmental Perspective of Urban Agriculture in Debre Markos Town Amhara Regional State Ethiopia.British Journal of Environmental Sciences, 4(2), 24-36. 
Boon Sung, C. T. (2012). Organic Agriculture and Food in Malaysia. Retrieved February 2012. http://www.christopherteh.com/blog/2012/02/organic-agriculture/

Dahlan, A., Ibrahim, S. A. S., \&Masuri, M. G. (2016). Role of the Physical Environment and Quality of Life amongst Older People in Institutions: A Mixed Methodology Approach. Procedia - Social and Behavioral Sciences, 234, 106113.

Davies, G., Devereaux, M., Lennartsson, M., Schmutz, U., \& Williams, S. (2014).The Benefits of Gardening and Food Growing for Health and Wellbeing. Growing Health Report.(pp. 46). London: Garden Organic and Sustain.

De Simone, S. (2015). Expectancy Value Theory: Motivating Healthcare Workers. American International Journal of Contemporary Research, 5(2), 19-23.

Department of Agriculture (2016). Kuala Lumpur: Department of Agriculture (DOA). Retrieved from www.doa.gov.my.

Engelbrech, W. H. (2011). Critical Success Factors for Managing the Visitor Experience at the Kruger National Park.(Master of Communication Tourism Management), North West University.

George, J.M. and Jones, G.R. (2012) Understanding and Managing Organizational Behaviour (6th edition). Harlow, Essex, England: Pearson Education

Mat, R., \& Abdul Majid, A. (2015).Kepentingan Pertanian Bandar danCabaran yang Dihadapi olehPetani Bandar di Malaysia. International Journal of Environment, Society and Space, 3(1), 44-56.

Mougeot, L. J. A. (2000). Urban Agriculture: Definition, Presence, Potentials and Risks, and Policy Challenges. Cities Feeding People. Ottawa, Canada: International Development Research Centre (IDRC).

Musthafa, S. N. A. M., Leh, O. L. H., Omar, D., \& Karuppannan, S. (2015). Theoretical Review on Environmental Health in Relation to Neighbourhood Planning and Human Physical Activity. Procedia - Social and Behavioral Sciences, 201, 325-332.

Naghibi, M. S., Faizi, M., Khakzand, M., \&Fattahi, M. (2015).Achievement to Physical Characteristics of Security in Residential Neighborhoods. Procedia - Social and Behavioral Sciences, 201, 265-274.

Nasrudin, N., Che Abdullah, I., \&Sapeciay, Z. (2010).Evaluating the Suitability of Urban Farming Programme (Case Study: Ipoh).UniversitiTeknologi MARA, Shah Alam.

Omar, Z. (2016). Kemiskinan Bandar Institut Penyelidikan Ekonomi Malaysia (MIER). Retrieved from https://www.mier.org.my/newsarticles/archives/pdf/DrZul22_08_2016.pdf

Persoon, L. (2016). Factors Influencing Sustainability Community Based Programs: A Mixed Method Study. (Master Health Education and Promotion), Maastricht University.

Purvis, R. L., Zagenczyk, T. J., \& McCray, G. E. (2015). What's in it for me? Using Expectancy Theory and Climate to Explain Stakeholder Participation, Its Direction and Intensity. International Journal of Project Management, 33(1), 3-14.

Ryan, R. M., \& Deci, E. L. (2000). Intrinsic and Extrinsic Motivations: Classic Definitions and New Directions. Contemp. Educ. Psychol., 25(1), 54-67.

Recknagel, C., Patton, B., \&Hugunin, P. (2016).Urban Agriculture in Minnesota. A Report to the Minnesota Legislature.United State: Minnesota Department of Agriculture. 
Othman, N., et.al. / Asian Journal of Quality of Life (AjQoL), 3(13) Sep/ Oct 2018 (p.8-17)

http://www.mda.state.mn.us/news/ /media/Files/news/govrelations/legrpt-urbanag2016.pdf

Smit, J., Nasr, J., \&R atta, A. (2001).Urban Agriculture - Food, Jobs and Sustainable Cities.(2011 Ed.).Great Falls, Virginia: The Urban Agriculture Network, Inc.

Vroom, V. H. (1964). Work and Motivation. New York: John Wiley \& Sons, Inc. 